\title{
Pollen spectrum of honey of Apis mellifera L. and stingless bees (Hymenoptera: Apidae) from the semi-arid region of Bahia State, Brazil
}

Polyana Carneiro dos Santos, Andreia Santos do Nascimento, Geni da Silva Sodré, Carlos Alfredo Lopes de Carvalho, Rogério Marcos de Oliveira Alves, Mariza Alves Ferreira, Brunelle Ramos Andrade, Maiara Janine Machado Caldas, Lorena Andrade Nunes \& Leticia Miranda Estevinho

To cite this article: Polyana Carneiro dos Santos, Andreia Santos do Nascimento, Geni da Silva Sodré, Carlos Alfredo Lopes de Carvalho, Rogério Marcos de Oliveira Alves, Mariza Alves Ferreira, Brunelle Ramos Andrade, Maiara Janine Machado Caldas, Lorena Andrade Nunes \& Leticia Miranda Estevinho (2020): Pollen spectrum of honey of Apis mellifera L. and stingless bees (Hymenoptera: Apidae) from the semi-arid region of Bahia State, Brazil, Grana, DOI: 10.1080/00173134.2020.1733074

To link to this article: https://doi.org/10.1080/00173134.2020.1733074

View supplementary material $₫$ Published online: 18 May 2020.

Submit your article to this journal $\pi$

山 Article views: 72

Q View related articles $\sqsubset$

View Crossmark data $\widetilde{ }$ 


\title{
Pollen spectrum of honey of Apis mellifera $\mathbf{L}$. and stingless bees (Hymenoptera: Apidae) from the semi-arid region of Bahia State, Brazil
}

\author{
POLYANA CARNEIRO DOS SANTOS ${ }^{1}$, ANDREIA SANTOS DO NASCIMENTO ® ${ }^{1}$, \\ GENI DA SILVA SODRÉ (1) ${ }^{1}$, CARLOS ALFREDO LOPES DE CARVALHO (1) ${ }^{1}$, \\ ROGÉRIO MARCOS DE OLIVEIRA ALVES (i) ${ }^{1}$, MARIZA ALVES FERREIRA ${ }^{1}$, \\ BRUNELLE RAMOS ANDRADE ${ }^{1}$, MAIARA JANINE MACHADO CALDAS ${ }^{1}$, \\ LORENA ANDRADE NUNES (i) ${ }^{2}$ \& LETICIA MIRANDA ESTEVINHO ${ }^{3}$
}

${ }^{1}$ Centro de Ciências Agrárias, Ambientais e Biológicas, Universidade Federal do Recôncavo da Bahia, Cruz das Almas, Brazil, ${ }^{2}$ Universidade Estadual do Sudoeste da Bahia, Jequié, Brazil, ${ }^{3}$ Centro de Investigação de Montanha (CIMO), Instituto Politécnico De Bragança, Bragança, Portugal

\begin{abstract}
Pollen in honey reflects its botanical origin and melissopalynology is used to identify origin, type, and quantities of pollen grains of the botanical species visited by bees. This study aimed to identify the pollen spectrum of honeys from Apis mellifera and stingless bees produced in the semi-arid region of Bahia, Brazil. We analysed 78 honey samples, which were submitted to the acetolysis process for identification and quantification of pollen types. Fabaceae, Asteraceae and Euphorbiaceae were the most predominant families in pollen types. For Fabaceae, the most representative pollen types were Chamaecrista 1, Mimosa caesalpiniifolia, Mimosa pudica, Mimosa tenuiflora, Prosopis and Senna. The results indicate that the flora explored by the bees to collect nectar is diverse in the semi-arid region of Bahia and the honeys analysed were classified as multifloral.
\end{abstract}

Keywords: melissopalynology, beekeeping, melliferous flora, pollen spectrum

The semi-arid region of Bahia, the Caatinga biome, is known for its characteristic botanical species adapted to dry, hot climatic conditions with rainfall unevenly distributed throughout the year (Velloso et al. 2002; Sousa et al. 2016a). It also contains a diversity of bees that favour honey production.

Drought is one of the main characteristics of the semiarid region of the Brazilian northeast. This region has an average annual precipitation between 250 and $500 \mathrm{~mm}$, and its vegetation is mainly formed by shrubs (Cirilo 2008). This region covers approximately $1219000 \mathrm{~km}^{2}$ (Cirilo 2008), highlighting the importance and the need to understand the uniqueness of beehive products obtained from this area. Pagano and Araújo (2010) reported on the diversity of the native vegetation of the Brazilian north-eastern semi-arid region. However, the pollen spectrum of beehive products of stingless bees (Melipona quadrifasciata anthidioides Lepeletier, 1836, Melipona scutellaris Latreille, 1811, Tetragonisca angustula Latreille, 1811) and Africanised bees (Apis mellifera, Linnaeus, 1758) of this region commonly displays a large number of representatives of Asteraceae, Fabaceae, Rubiaceae and Myrtaceae (Novais et al. 2013, 2015; Costa et al. 2015; Oliveira et al. 2016).

The pollen analyses of beehive products from the semi-arid region of Bahia show a major predominance for pollen stored by the bees (bee pollen) (Novais et al. 2009; Oliveira et al. 2016; Carneiro Neto et al. 2017). However, honey is the best known and most consumed product of bees (Tsutsumi \& Oishi 2010). Thus, the honey produced in the semiarid region may present an attractive sensory profile

Correspondence: Polyana Carneiro dos Santos, Centro de Ciências Agrárias, Ambientais e Biológicas, Universidade Federal do Recôncavo da Bahia, Rua Rui Barbosa, n 710, Centro, Cruz das Almas, Bahia 44380-000, Brazil. E-mail: polyufba@yahoo.com.br 
to consumers and these characteristics are directly related to the flora visited by the bee to collect nectariferous resources. Thus, the identification of floral origins explored by bees is relevant to characterise and value beehive products for the market.

When bees visit flowers to collect nectar, they adhere body pollen grains that mix with nectar at regurgitation (Nogueira-Neto 1997; Santana et al. 2011). Pollen in honey reflects its botanical origin as each botanical species has flowers with a specific pollen type, allowing identification of the floral source of honey nectar. The floral source that bees use in producing honey can be identified by melissopalynology, a useful tool to identify the presence, absence, type and amount of pollen of certain botanical species that bees use, indicating their potential for bee rearing (Louveaux et al. 1978; Silva \& Santos 2014).

The determination of the botanical origin is used to label honey. The knowledge of the geographic origin are factors that influence considerably the commercial value of the product and can still be used as a screening tool for quality control (Barth et al. 2013; Corvucci et al. 2015). Nevertheless, despite its importance, little information is available on honey from stingless bees of the Bahia semi-arid. Therefore, our study aimed to identify the pollen spectrum of Apis mellifera honeys and stingless bees (Meliponinae) produced in the semi-arid region of the state of Bahia, Brazil.

\section{Material and methods}

\section{Study site and sampling}

Samples were collected in ten municipalities in the semi-arid region of Bahia, Brazil (Figure 1). The semiarid region covers more than $50 \%$ of Bahia State, presenting a highly diversified flora, as recorded by Ramalho et al. (2009). Honeys were harvested from eight bee species, totalling 78 samples, composed of approximately $250 \mathrm{~g}$, in one year of sampling (Table I). Samples were collected in each municipality according to bee species and the availability of honey produced in the period (Table I).

\section{Pollen analysis}

The methodology described by Louveaux et al. (1978), following modifications proposed by Jones and Bryant Junior (2004) was used as the basis for preparation of the samples and later submitted to the acetolysis process of Erdtman (1960). The pollen sediment resulting from the acetolysis process was used to prepare slides with glycerine gelatine for identification and counting of pollen grains that comprise the pollen spectrum of the sample.

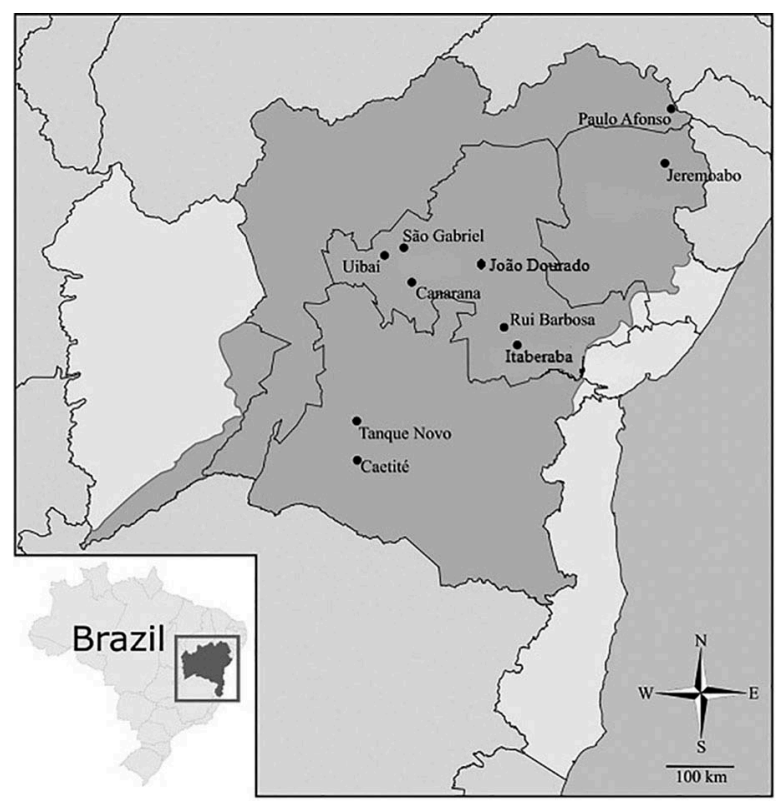

Figure 1. Geographic location of the study site, where samples of honey samples were collected in the semi-arid region of Bahia, Brazil.

The pollen types were identified using specialised literature such as Barth (1989), Roubik and Moreno (1991), Punt et al. (2007), Lorente et al. (2017), Ybert et al. $(2017,2018)$ and consulting database and images of the Palinoteca of the Federal University of the Recôncavo of Bahia (Insect Study Group/Insecta). For that purpose, images of each pollen type were captured per sample using an Olympus ${ }^{\circledR}$ optical microscope (CX41) fitted with an Olympus ${ }^{\circledR}$ digital camera (E-330).

To determine the frequency classes of the pollen types in the honey samples, the consecutive counting of up to 1000 pollen grains/sample was performed according to Louveaux et al. (1978), classified as: predominant pollen - PP ( $>45 \%$ of total grains), secondary pollen - SP (16 to $45 \%$ ), important minor pollen IMP (3 to $15 \%$ ) and minor pollen - MP (<3\%). Additionally, we calculated the frequency of occurrence of each pollen type in the samples using the equation: $\mathrm{FO}=(\mathrm{ni} / N) \times 100$, where $\mathrm{FO}$ is the frequency of occurrence of the pollen type in the sample, ni is the number of pollen grains of the pollen type counted in the sample; $N$ is the total number of pollen grains counted in the sample. According to Feller-Demalsy et al. (1987) we established the frequency classes: > $50 \%$ of samples, very frequent $(\mathrm{VF}) ; 20-50 \%$, frequent (F); $10-20 \%$ infrequent $(\mathrm{I}) ;<10 \%$, rare (R).

\section{Multivariate statistical analysis}

The principal component analysis (PCA) and biplot were used to identify the association and prevalence of pollen types and bees species. The cluster analysis 
Table I. Sampling of honey from the semi-arid region of Bahia, Brazil.

\begin{tabular}{lcc}
\hline Species of bee & Number samples & Sampling site (municipality) \\
\hline Apis mellifera Linnaeus, 1758 & $(n=7)$ & Canarana Itaberaba Rui Barbosa \\
Melipona asilvai Moure, 1971 & $(n=8)$ & Itaberaba Jeremoabo São Gabriel \\
Melipona mandacaia Smith, 1863 & $(n=24)$ & Uibaí João Dourado São Gabriel \\
Melipona quadrifasciata anthidioides Lepeletier, 1836 & $(n=12)$ & São Gabriel Tanque Novo \\
Melipona quadrifasciata Lepeletier, 1836 & $(n=5)$ & Jeremoabo \\
Melipona subnitida Ducke, 1910 & $(n=12)$ & Paulo Afonso \\
Scaptotrigona sp. & $(n=6)$ & Canarana UibaíRui Barbosa \\
Tetragonisca angustula Latreille, 1811 & $(n=4)$ & Rui Barbosa Caetité Canarana \\
\hline
\end{tabular}

was carried out by the unweighted pair group method with arithmetic mean (UPGMA) using Palaeontological Statistics Software (PAST) v.1.34.

The cophenetic correlation coefficient (CCC) was calculated based on the similarity matrix and the dendrogram. To evaluate the adhesion between the dendrogram and the similarity matrix of Jaccard, the cophenetic correlation of Mantel was estimated using the PAST v.1.34 (Hammer et al. 2001).

\section{Results}

In the pollen spectrum of the honeys analysed, we identified 64 pollen types distributed in 26 families and two pollen types were not possible to be identified. The indeterminate pollen types occurred as minor pollen $(\mathrm{MP}<3 \%)$ in the samples (Table II). The richest family in pollen types was Fabaceae with $35.94 \%$ of the total identified types, followed by Asteraceae (7.81\%) and Euphorbiaceae (6.25\%), (Figure 2). For Fabaceae, the most representative ( $\mathrm{FO}>50 \%$ of samples) pollen types in the samples were Mimosa caesalpiniifolia, Mimosa tenuiflora and Prosopis (Table II). The most frequent (FO General > 75\%) pollen types in the samples were Acacia, Borreria, Mimosa caesalpiniifolia, Mimosa tenuiflora, Prosopis, Psidium, Schinus, Solanum and Rubiaceae type, among which, only Prosopis types was identified in the honey pollen spectrum of all bees (Figures 3, 4, Table II).

The pollen type Mimosa tenuiflora was found in all samples of Melipona quadrifasciata anthidioides and Melipona quadrifasciata with frequency also above $70 \%$ (very frequent) in the samples of Melipona asilvai, Melipona mandacaia and Melipona subnitida. Additionally, Mimosa tenuiflora was observed in the honey of these species of stingless bees as predominant pollen and/or secondary pollen, except for Melipona quadrifasciata. In the honey evaluated, there were 11 pollen types as predominant pollen and 22 as secondary pollen (Table III).

The pollen type Mimosa caesalpiniifolia was frequent in most honeys of the bee species studied, more frequent in honeys of Melipona quadrifasciata anthidioides and Apis mellifera. For Melipona mandacaia, the Waltheria type was present in $100 \%$ of the samples of honey (Table II).

The pollen types Chamaecrista $(1,2,3)$ and Croton $(1,2,3)$ were separated in three different types because they were identified in samples from different municipalities. Pollen morphology studies show that for Chamaecrista Moench. and Croton L. pollen size variation is elevated in the same specimen and is not indicative of different species (Carreira et al. 1996; Lima et al. 2007; Nascimento \& Del-Claro 2007).

\section{Multivariate statistical analysis}

The PCA showed that the first three main components were sufficient to explain $72.8 \%$ of the total variation. The first PCA explained $37.3 \%$ of this variation, which can be verified in the biplot graph that shows that Mimosa tenuiflora was the pollen type that most contributed to the first PCA (Figure 5). We also observed four groups with cluster analysis (Figure 6).

\section{Discussion}

In our study, Fabaceae had the highest number of pollen types. Species of this taxonomic group are described as suppliers of trophic resources (nectar and pollen) for bees. In addition, this family is considered the most abundant in the studied region (Alves et al. 2016; Matos \& Santos 2016).

The high representation of pollen grains from the Fabaceae in honey samples is because this family is well represented in the Brazilian semi-arid region, with the largest number of species in the Caatinga and Cerrado (Queiroz et al. 2006). Another family also considered important and found in the honeybee pollen spectrum was Asteraceae. Generally reported as potential bee plants species of genera Baccharis, Bidens, Centratherum, Cosmos, Helianthus, 


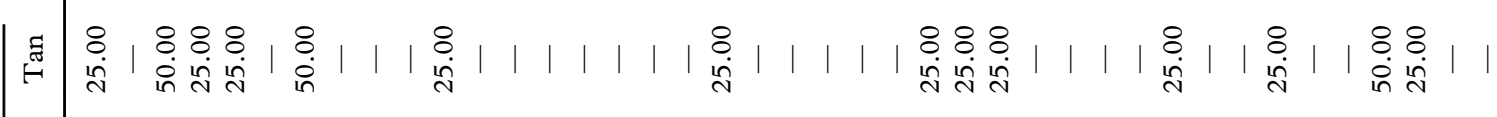

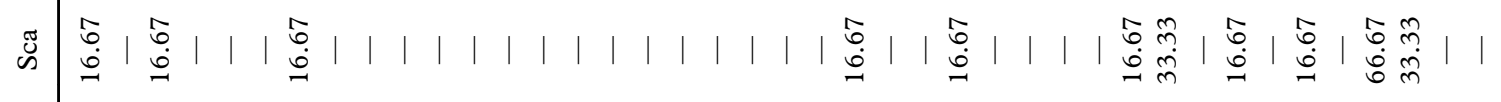

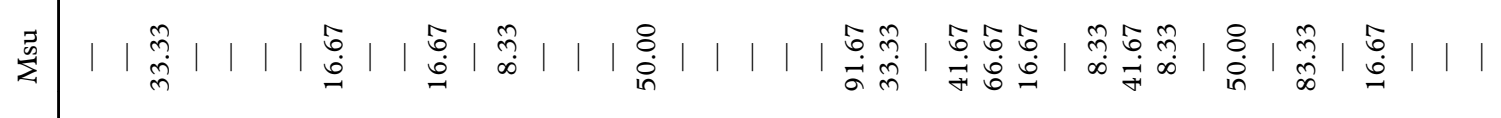
急|

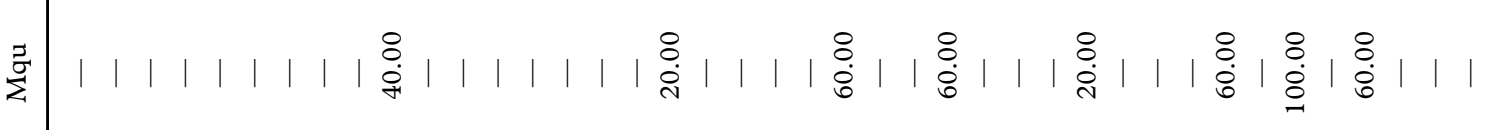

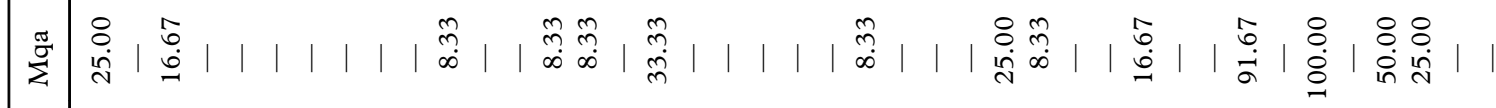

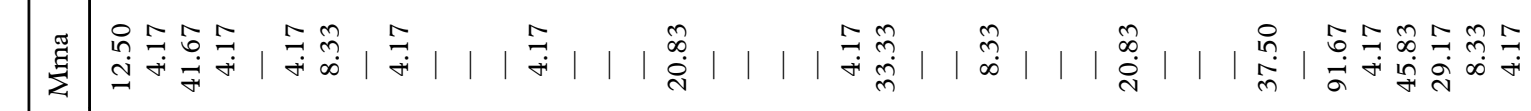

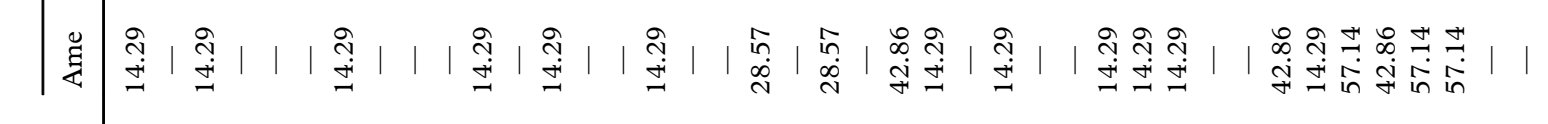

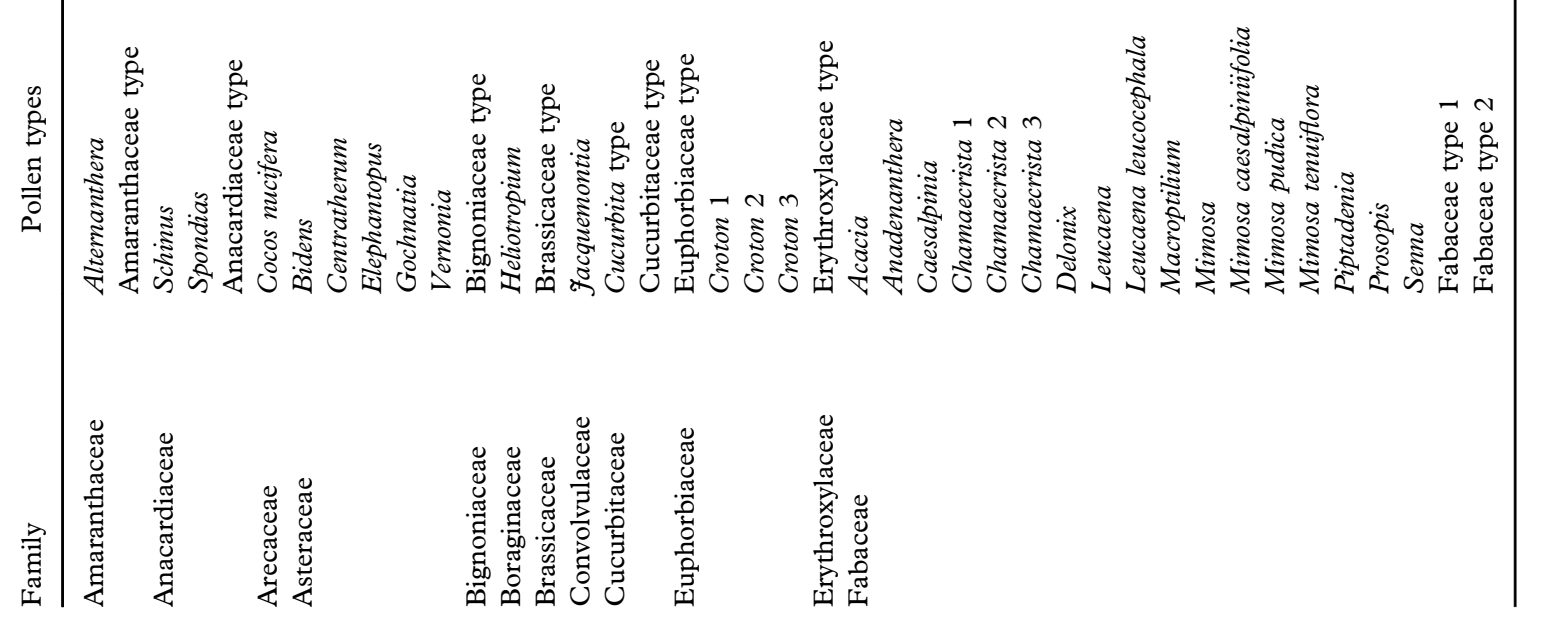




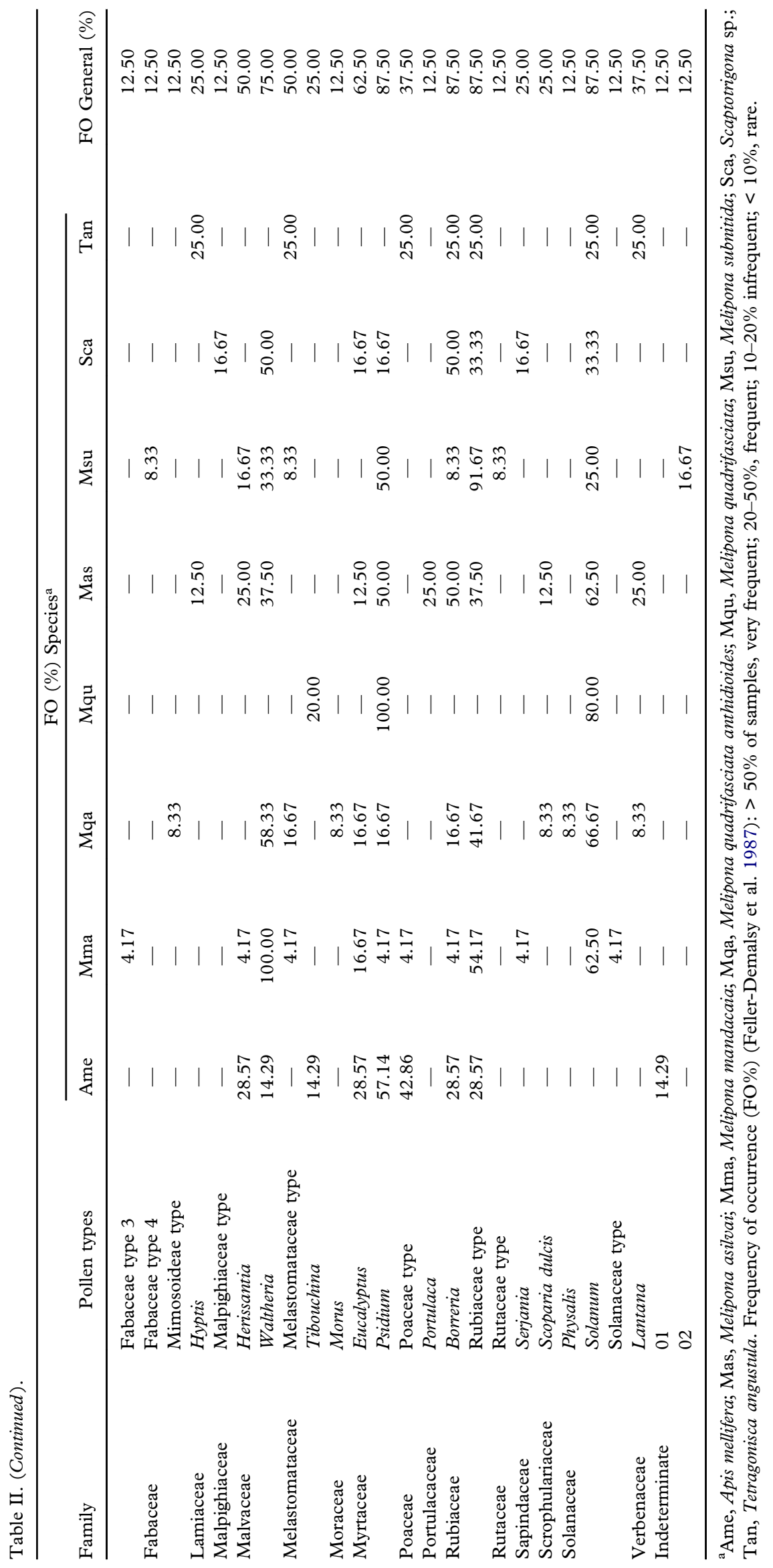




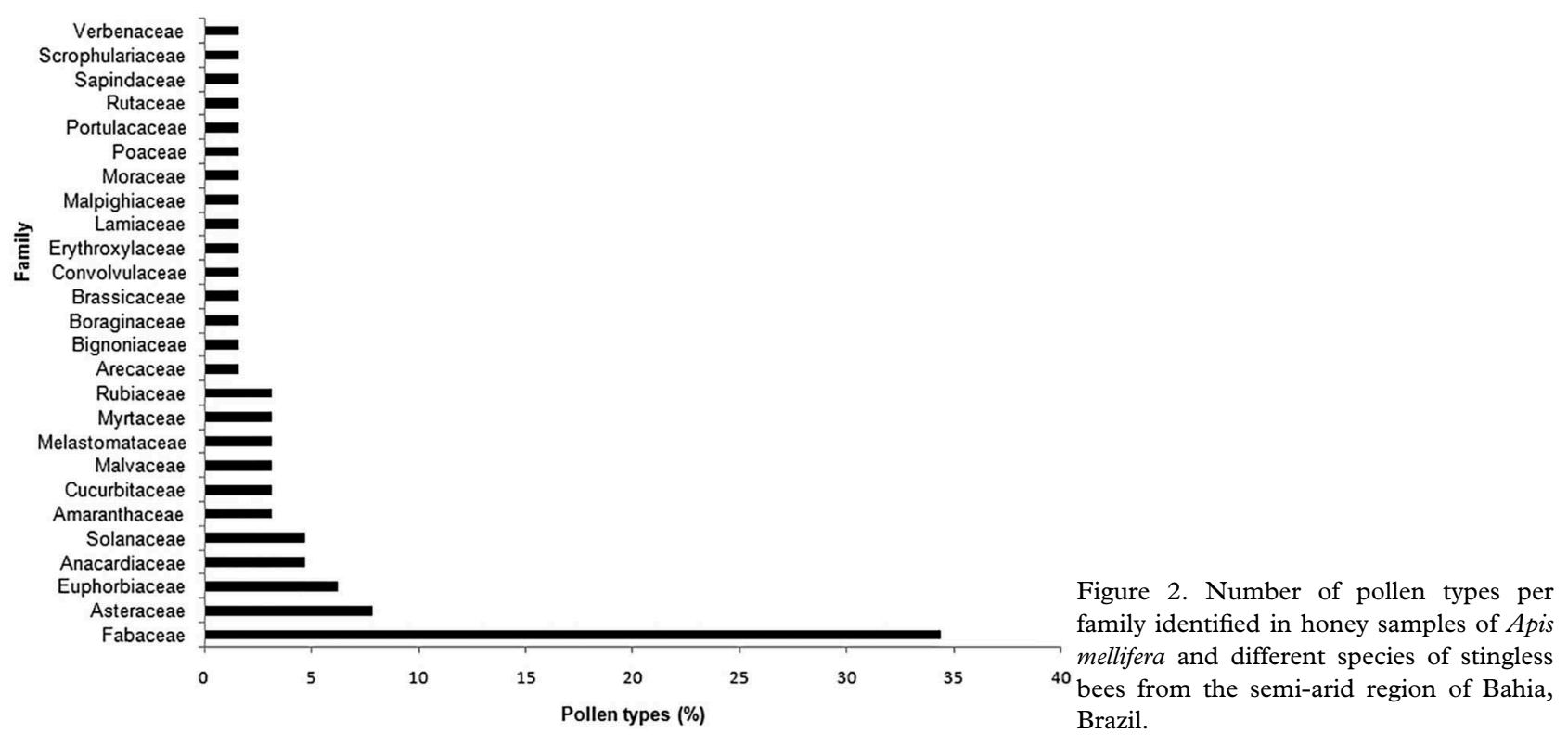

Mikania and Vernonia (Borges et al. 2014; Nascimento et al. 2015; Matos \& Santos 2016).

Among the most frequent pollen types in the samples of all bee species, the types Acacia, Prosopis and Solanum are highlighted. Prosopis, as well as species of the genus Acacia (Fabaceae-Mimosoideae), are very common in the studied region, playing a very important role for bees (Santos \& Carneiro 2015). This fact can be verified by the registration of pollen types Prosopis and Acacia in the samples evaluated (Table II). The species Prosopis juliflora (Sw) DC. is very common in the Caatinga and highly used for animal feed (Braga et al. 2009; Oliveira et al. 2010). Prosopis juliflora offers both pollen and nectar, becoming attractive to bees (Sousa et al. 2016b).

The pollen type Mimosa tenuiflora was present in $100 \%$ of honey samples of bee species Melipona quadrifasciata anthidioides and Melipona quadrifasciata, with frequency above $70 \%$ for the other bees of the genus Melipona in this study. This result indicates that Mimosa tenuiflora is preferred by these bee species. Although the pollen spectrum of the analysed honey is diverse, probably these bees are more attracted by this plant species (Figure 5, Table I). The Mimosa tenuiflora (Willd) Poir. species is very attractive to bees, a source of pollen and nectar, being a species characteristic of the Caatinga. Its flowering occurs during a period of little floral abundance, providing great pollen amount to bees. It is also considered a potential species for bee rearing in the semi-arid region of Bahia (Calixto Júnior et al. 2011; Maia-Silva et al. 2012).

Another pollen type that occurred in most samples studied was Mimosa caesalpiniifolia. The species
Mimosa caesalpiniifolia Benth. presents great potential for afforestation, hedge and wood production (Alves et al. 2002). This species is considered exotic and is used as trophic resources (pollen and nectar) by bees. The use of these plants by bees can be confirmed by the frequency in $75 \%$ of the honeys studied. Studies carried out on stingless bee honeys and Apis mellifera by Souza et al. (2015) and Nascimento et al. (2015), respectively, identified pollen types of the genus Mimosa, for example, Mimosa caesalpiniifolia, Mimosa verrucosa, Mimosa arenosa, Mimosa quadrivalvis and Mimosa pudica. The diversity of species of the genus Mimosa is indicative of the food preference of different species of bees by these plants.

In Melipona mandacaia samples, Waltheria type had $100 \%$ frequency and occurred as predominant pollen (PP) in $52 \%$ of the samples (Table II). Although other plant species (pollen types) were found in the honeybee pollen spectrum, which contribute to honey composition, there is possibly a preference for these bees to collect nectar in Waltheria. Due to the attractiveness of Waltheria spp. (Malvaceae) for bees, beekeepers recognise this plant as excellent to compose the bee flora, considered a nectariferous plant. Silva et al. (2013) and Oliveira and Santos (2014) identified the Waltheria pollen type in honeys of stingless bee and Apis mellifera.

The abundance of these spontaneous plants (Waltheria spp.) can be considered the main attractive factor for bees, since these plants produce small flowers and probably secretion of nectar is low (Kill et al. 2000; Maia-Silva et al. 2012). Castro (1994) defines useful plants for bees with abundant occurrence in the 

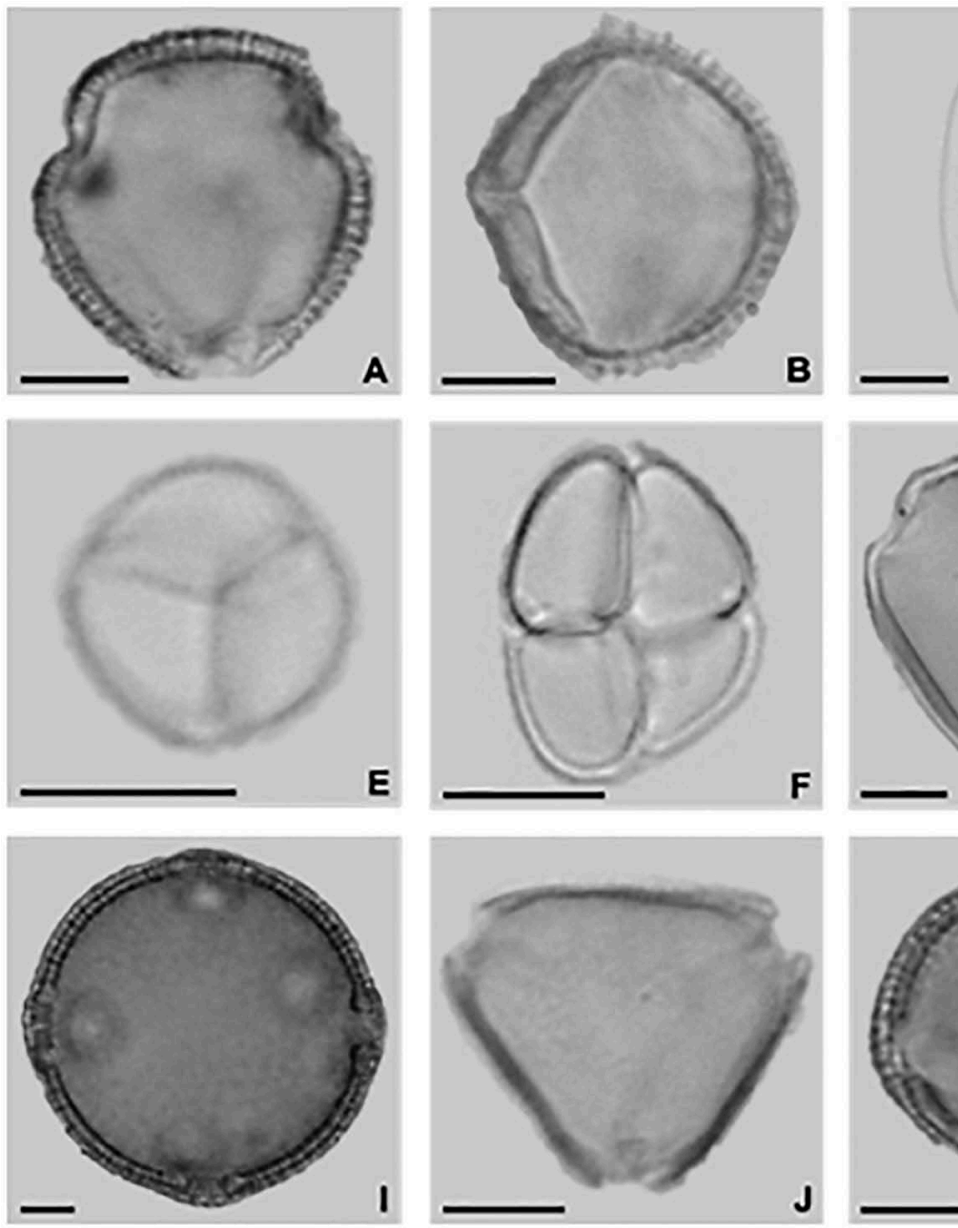
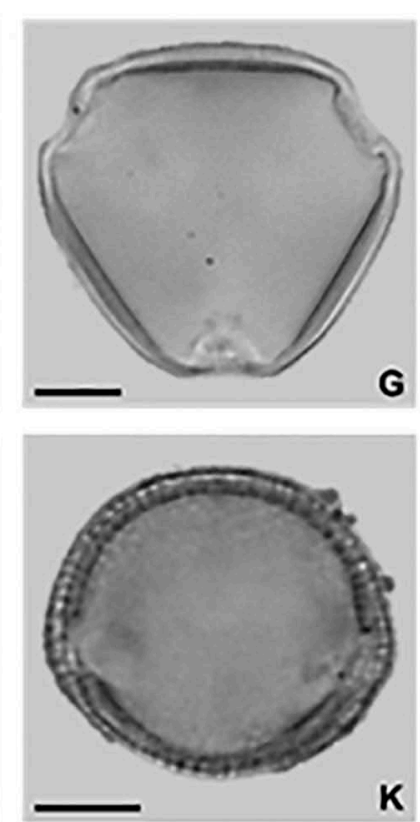
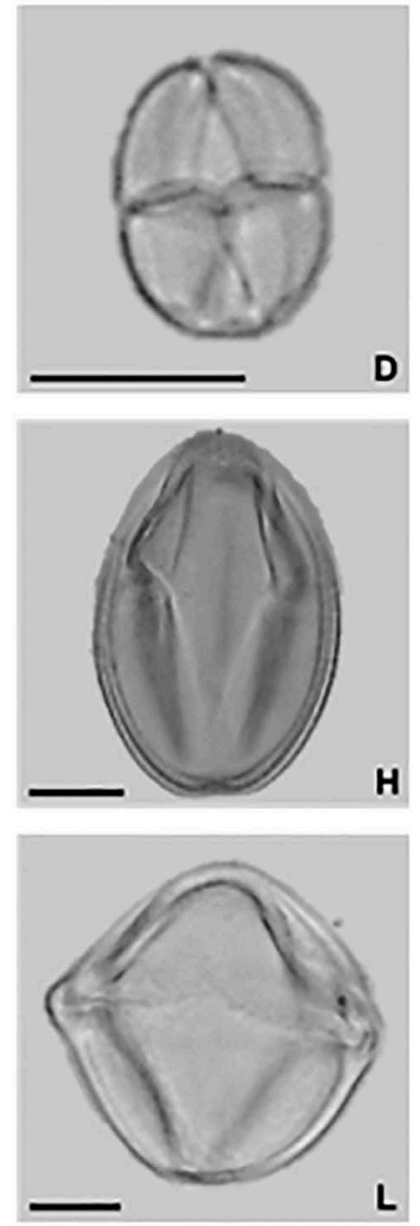

Figure 3. Photomicrography of predominant pollen (PP) types in Apis mellifera honey and stingless bees from the semi-arid region of Bahia, being EV (equatorial view) and PV (polar view). A, B. Anacardiaceae: Schinus, A. Polar view. B. Equatorial view. C. Fabaceae: Chamaecrista 1 (EV). D. Fabaceae: Mimosa caesalpiniifolia (PV). E. Fabaceae: Mimosa pudica (PV). F. Fabaceae: Mimosa tenuiflora (PV). G. Fabaceae: Prosopis (PV). H. Fabaceae: Senna (EV). I. Malvaceae: Waltheria (PV). J. Myrtaceae: Psidium (PV). K. Rubiaceae: Borreria (PV). L. Solanaceae: Solanum (EV). Scale bars $-10 \mu \mathrm{m}$.

area for breeding these individuals, blooming copiously with nectar and pollen available for bees. Therefore, Waltheria can be considered an important plant for beekeeping for the semi-arid region of Bahia.

Frequent presence of Solanum type in the honey samples analysed can be a consequence of contamination, as this species of this genus have poricidal anther, through which they release dry pollen, and are pollinated by vibration, besides not secreting nectar (Willmer 2011; Nunes-Silva et al. 2013). Thus, although species of the Solanum genus do not contribute to honey composition with nectar volume, their identification in the pollen spectrum of the evaluated honeys helps characterise the flora explored by bees in the sites surrounding the apiaries. The Solanum type was also identified in the pollen spectrum of the honeys evaluated by Nasci- mento et al. (2015), Souza et al. (2015), Falcão et al. (2016) and Matos and Santos (2016).

The honeys studied for Apis mellifera or stingless bees are multifloral, except for a sample of Scaptotrigona sp. The occurrence of multifloral honeys is due to the great diversity of native flora of the region, which allows bees to explore a range of plants providing trophic resources of the various botanical families. Regardless of the bee species that produce the honey, we observed that they forage several species to form their diet (Table II). This fact can add value to the product, since Brazilian honeys have peculiar sensorial characteristics according to the region of origin (Sousa et al. 2016a).

The search for food by bee Scaptotrigona sp. in a single plant species, Senna type (Fabaceae), may be related to several factors such as resources available during scarce period of collection, abundance and 

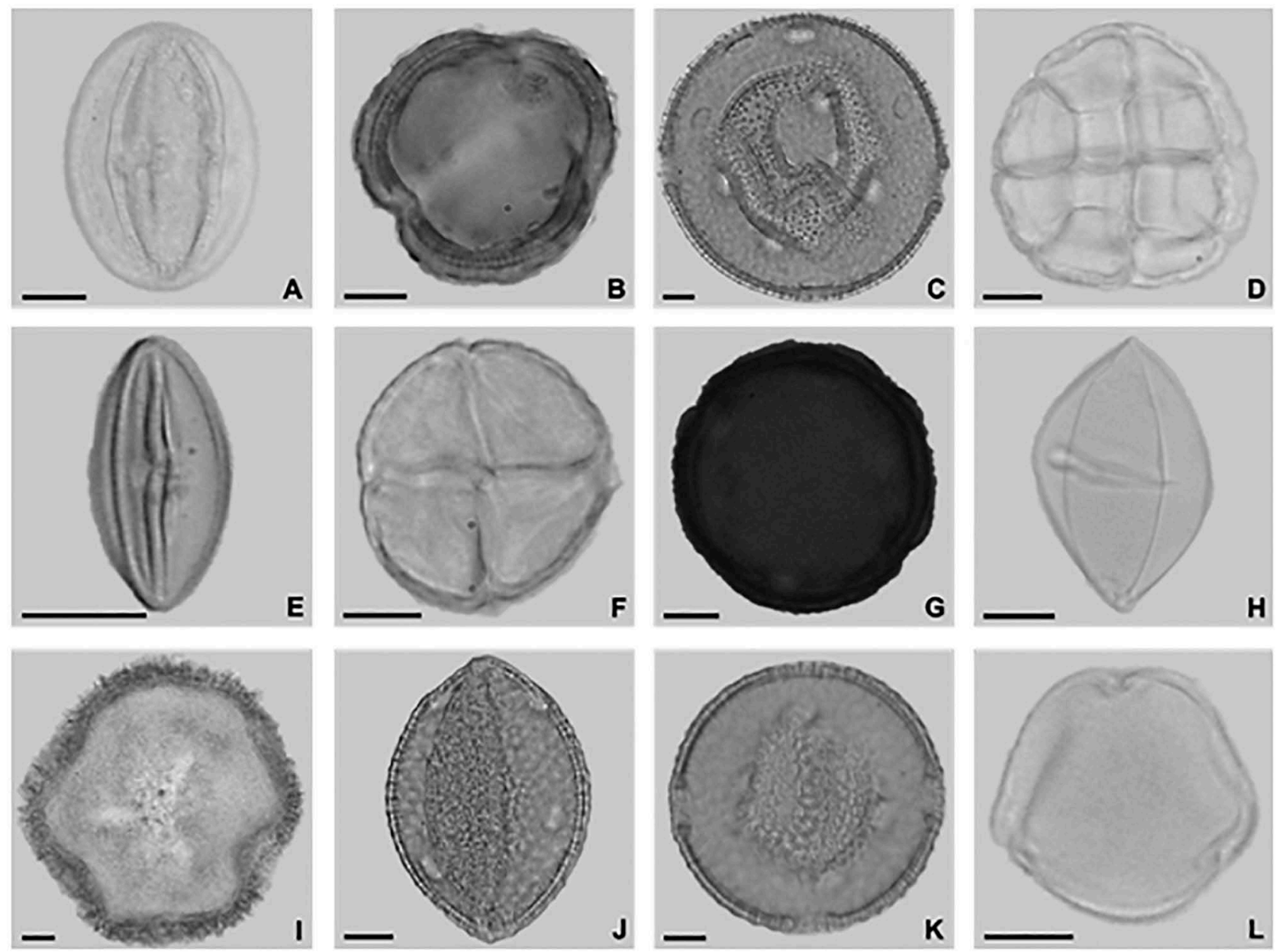

Figure 4. Photomicrography of secondary pollen (SP) types in Apis mellifera honey and stingless bees from the semi-arid region of Bahia, being EV (equatorial view) and PV (polar view). A. Anacardiaceae: Spondias (EV). B. Asteraceae: Gochnatia (PV). C. Cucurbitaceae: Cucurbitaceae type (PV). D. Fabaceae: Acacia (PV). E. Fabaceae: Chamaecrista 2 (EV). F. Fabaceae: Mimosoideae type (PV). G. Malpighiaceae: Malpighiaceae type (PV). H. Poaceae: Poaceae type (EV). I. Portulacaceae: Portulaca (PV). J. Rubiaceae: Rubiaceae type (EV). K. Rubiaceae type (PV). L. Verbenaceae: Lantana (PV). Scale bars - $10 \mu \mathrm{m}$.

proximity of plant species of the genus Senna within the radius of action of this bee. Osterkamp and Jasper (2013) report that the large number of pollen types identified in honeys hinders determination of the exact species that contributed to honey composition. This was also observed in our study.

The multivariate statistical analysis revealed that the pollen type Mimosa tenuiflora was collected mainly by bees Melipona quadrifasciata and Melipona mandacaia, and this pollen type contributed more to the first PCA. This component is also influenced by the Acacia type, mainly collected by Melipona subnitida. The second PCA explains $20.9 \%$ of the variation and is influenced by pollen type Chamaecrista 2, which was also collected by Melipona subnitida. The first and second PCA are presented in Figure 5.
The third component explains about $14.6 \%$ of the total variation and was influenced by Chamaecrista 1 and by the collection in plant species represented by the pollen type Leucaena leucocephala for Scaptotrigona sp., Prosopis for Apis mellifera and Mimosa pudica for Melipona asilvai. In addition, Scaptotrigona sp. and A. mellifera show preference for Piptadenia type. The cluster analysis, using the UPGMA method, corroborates the results obtained in the PCA (Figure 6).

Additionally, the cluster analysis showed a cophenetic correlation of $86 \%$ and formation of four groups, two groups formed by only one bee species, Scaptotrigona sp. and Melipona subnitida. The separation of these species of bees occurred due to food preference for an unusual floral resource by the other bee species. 
Table III. Predominant pollen (PP) and secondary pollen (SP) types identified in Apis mellifera honeys from stingless bees, from the semiarid region of Bahia.

\begin{tabular}{|c|c|c|}
\hline \multirow[b]{2}{*}{ Bee species } & \multicolumn{2}{|r|}{ Pollen types } \\
\hline & PP & $\mathrm{SP}$ \\
\hline Apis mellifera & Mimosa caesalpiniifolia; Mimosa tenuiflora & $\begin{array}{l}\text { Acacia; Borreria; Mimosa caesalpiniifolia; Mimosa tenuiflora; Prosopis; } \\
\text { Poaceae type; Waltheria }\end{array}$ \\
\hline Melipona asilvai & $\begin{array}{l}\text { Mimosa caesalpiniifolia; Mimosa pudica; } \\
\text { Solanum; Waltheria }\end{array}$ & $\begin{array}{l}\text { Borreria; Chamaecrista 2; Lantana; Mimosa tenuiflora; Portulaca; } \\
\text { Prosopis; Psidium; Solanum }\end{array}$ \\
\hline M. mandacaia & $\begin{array}{l}\text { Mimosa caesalpiniïfolia; Mimosa tenuiflora; } \\
\text { Prosopis; Waltheria; Solanum }\end{array}$ & $\begin{array}{l}\text { Chamaecrista 1; Mimosa tenuiflora; Prosopis; Senna; Solanum; Schinus; } \\
\text { Cucurbitaceae type; Rubiaceae type; Waltheria }\end{array}$ \\
\hline $\begin{array}{l}\text { M. quadrifasciata } \\
\text { anthidioides }\end{array}$ & $\begin{array}{l}\text { Mimosa caesalpiniïfolia; Mimosa tenuiflora; } \\
\text { Waltheria }\end{array}$ & $\begin{array}{l}\text { Lantana; Mimosa caesalpiniifolia; Mimosa tenuiflora; Senna; } \\
\quad \text { Mimosoideae type; Solanum; Waltheria }\end{array}$ \\
\hline M. quadrifasciata & $\begin{array}{l}\text { Mimosa caesalpiniïfolia; Chamaecrista } 1 \text {; } \\
\text { Solanum; Psidium }\end{array}$ & Gochnatia; Mimosa tenuiflora \\
\hline M. subnitida & Mimosa caesalpiniïfolia; Mimosa tenuiflora & $\begin{array}{l}\text { Acacia; Chamaecrista 1; Chamaecrista 2; Macroptilium; Mimosa } \\
\text { tenuiflora; Rubiaceae type }\end{array}$ \\
\hline Scaptotrigona sp. & Mimosa caesalpiniifolia; Prosopis; Senna & $\begin{array}{l}\text { Mimosa tenuiflora; Prosopis; Solanum; Schinus; Malpighiaceae type; } \\
\text { Waltheria }\end{array}$ \\
\hline $\begin{array}{l}\text { Tetragonisca } \\
\text { angustula }\end{array}$ & Borreria; Solanum; Schinus & Lantana; Prosopis; Spondias; Rubiaceae type; Waltheria \\
\hline
\end{tabular}

Note: PP (more than $45 \%$ of the pollen grains counted) and SP (16-45\%) (Louveaux et al. 1978).

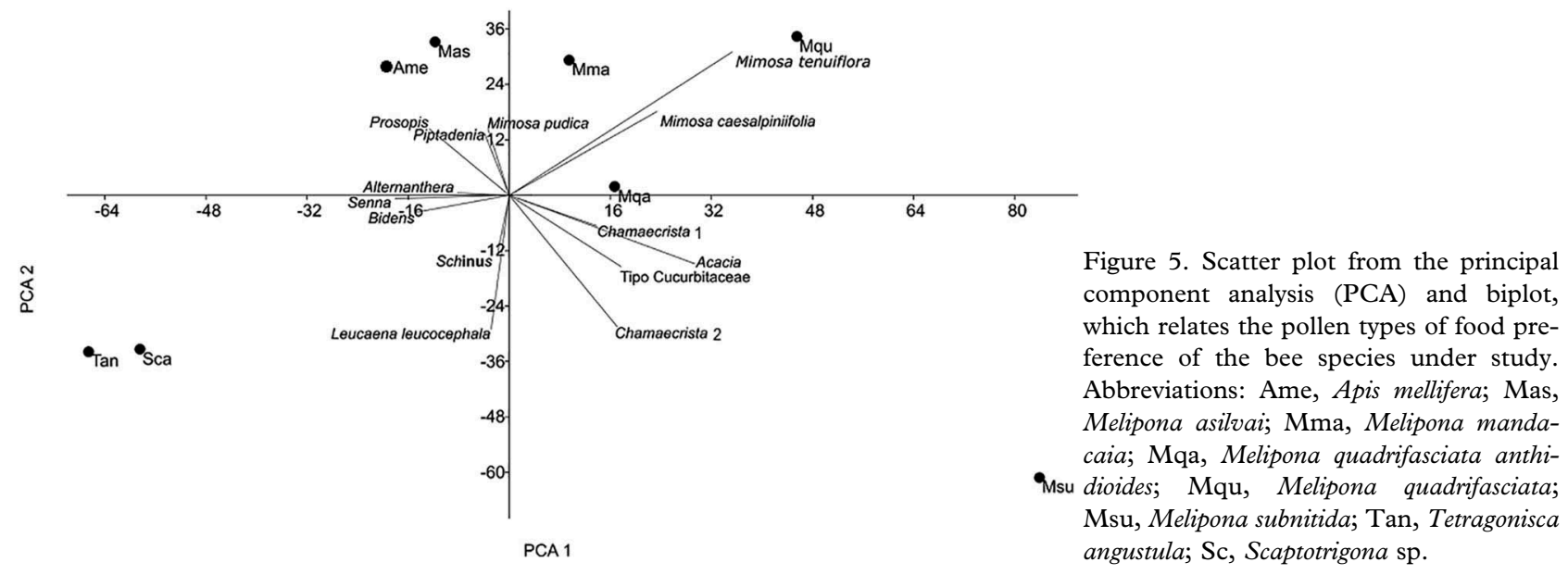

Scaptotrigona sp. as food resource species was represented by the pollen types Physalis and Facquemontia and Melipona subnitida by Macroptilium type.

The cluster analysis revealed similarity in the nectariferous resources visited by Apis mellifera, Melipona quadrifasciata anthidioides and Melipona quadrifasciata in the semi-arid region of Bahia (FigFigure 6). These social bees share pollen types of Fabaceae as the most frequent plants for honey composition (Figure 5 and Tables II and III). Another group is formed by Melipona asilvai and Melipona mandacaia showing greater similarity in the composition of its pollen spectrum. This indicates that if these bee species are managed in the same environment, there may occur trophic niche overlap. Gostinski et al. (2018) conducted a study in the Amazon region in Brazil and observed high niche overlap for stingless bees.

Melipona subnitida and Scaptotrigona sp. showed no evidence of group formation with the other species of stingless bees, possibly due to the volume contribution of nectar of each plant visited by the bees. The separation of these species of bees occurred due to food preference for an unusual floral resource by the other bee species. Scaptotrigona sp. as food resource species was represented by the pollen types Physalis and Facquemontia and Melipona subnitida by Macroptilium type.

\section{Conclusions}

The identification of pollen types in honeys from the semi-arid region of Bahia allowed their classification as 


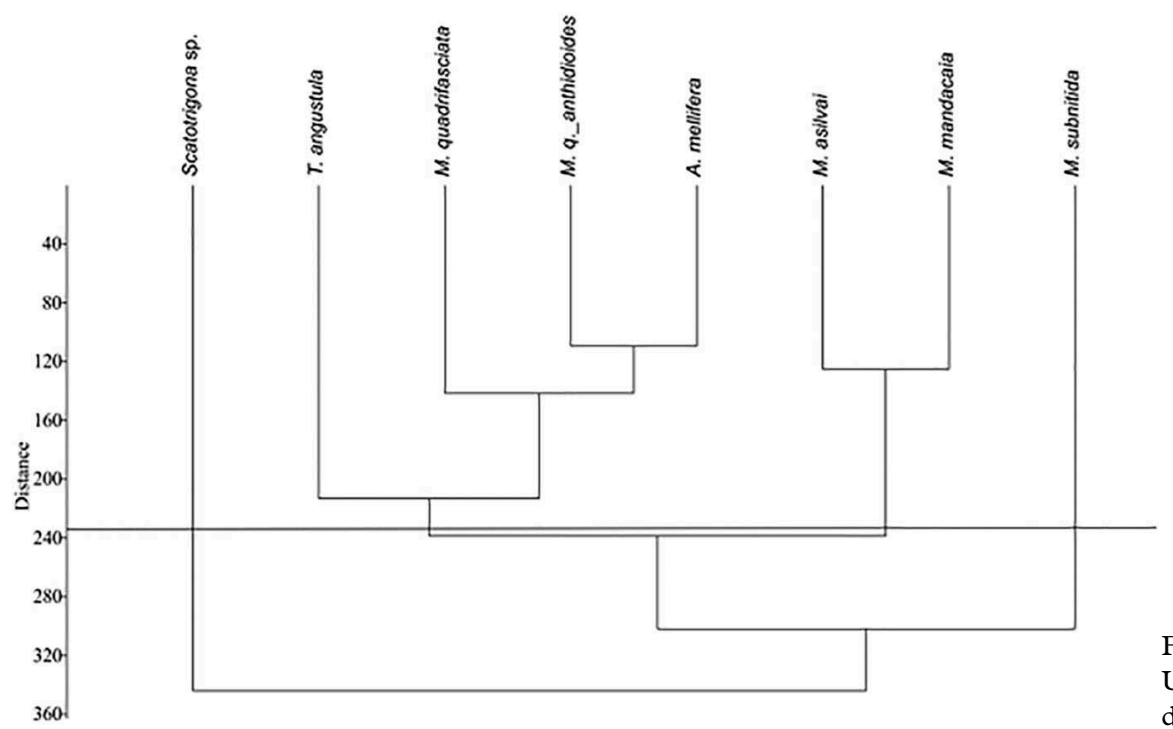

Figure 6. Grouping analysis by the UPGMA method showing preference of different bee species to the flora. multifloral honeys, with an expressive contribution of pollen types of the Fabaceae family, predominantly, Chamaecrista, Mimosa tenuiflora, Mimosa caesalpiniifolia, Prosopis and Senna. The large number of pollen types identified in honey samples demonstrates the great vegetation diversity in the semi-arid region of Bahia, Brazil.

\section{Disclosure Statement}

No potential conflict of interest was reported by the authors.

\section{Supplementary material}

Supplemental data for this article can be accessed here.

\section{ORCID}

Andreia Santos do Nascimento (D) http://orcid.org/00000001-5236-0460

Geni da Silva Sodré (D) http://orcid.org/0000-0002-61844720

Carlos Alfredo Lopes de Carvalho (D) http://orcid.org/00000002-3306-3003

Rogério Marcos de Oliveira Alves (D) http://orcid.org/00000002-8888-209X

Lorena Andrade Nunes (D) http://orcid.org/0000-00027453-7666

Leticia Miranda Estevinho (D) http://orcid.org/0000-00029249-1948

\section{References}

Alves EU, Paula RC, Oliveira AP, Bruno RLA, Diniz AA. 2002. Germination of Mimosa caesalpiniaefolia Benth seeds under differ- ent substrates and temperatures. Revista Brasileira De Sementes 24: 169-178. doi:10.1590/S0101-31222002000100025.

Alves RMO, Carvalho CAL, Waldschmidt AM, Paixão JF, Souza BA, Santos LOF, Sodré GS, Souza IC, Silva OS, Oliveira MP. 2016. Melipona mandacaia Smith, 1983: A abelha da Caatinga do Velho Chico. Curitiba: CRV.

Barth OM. 1989. O pólem no mel brasileiro. Rio de Janeiro: Luxor.

Barth OM, Freitas AS, Almeida-Muradian LB, Vit P. 2013. Palynological analysis of Brazilian stingless bee pot-honey. In: Vit $\mathrm{P}$, Roubik D, eds. Stingless bees process honey and pollen in cerumen pots, 1-8. Mérida: Universidade de Los Andes.

Borges RLB, Jesus MC, Camargo RCR, Santos FAR. 2014. Pollen content of marmeleiro (Croton spp., Euphorbiaceae) honey from Piauı State, Brazil. Palynology 38: 179-194. doi:10.1080/01916122.2014.880077.

Braga AP, Ezequiel JMB, Braga ZCAC, Mendonça Júnior AF. 2009. Chemical composition and digestibility of pods of mesquite (Prosopis juliflora (SW) DC.) submitted to different thermic treatments. Revista Caatinga 22: 257-263.

Calixto Júnior JT, Drumond MA, Alves Júnior FT. 2011. Structure and spatial distribution of Mimosa tenuiflora (Willd.) Poir. in two caatinga fragments in Pernambuco. Revista Caatinga 24: 95-100.

Carreira LMM, Secco RS, Barth OM. 1996. Pollen morphology of the lianescent species of the genus Croton (Euphorbiaceae). Grana 35: 74-78. doi:10.1080/00173139609429476.

Carneiro-Neto TFS, Rebouças PO, Pereira JE, Duarte PM, Santos MHLC, Silva GC, Siqueira KMM. 2017. Spectrum of pollen stored by Melipona mandacaia (Smith, 1863) (Hymenoptera: Apidae, Meliponini) in an urban arid landscape. Sociobiology 64: 284-291. doi:10.13102/sociobiology.v64i3.1257.

Castro MS. 1994. Plantas apícolas: Identificação e caracterização. In: Brandão ALS, Boaretto MAC, eds. Apicultura atual: Diversificação de produtos, 21-31. Vitória da Conquista: UESB.

Cirilo JA. 2008. Public water resources policy for the semi-arid region. Estudos Avançados 22: 61-82. doi:10.1590/S010340142008000200005.

Corvucci F, Nobili L, Melucci D, Grillenzoni FV. 2015. The discrimination of honey origin using melissopalynology and Raman spectroscopy techniques coupled with multivariate 
analysis. Food Chemistry 169: 297-304. doi:10.1016/j.foodchem.2014.07.122.

Costa SN, Alves RMO, Carvalho CAL, Conceição PJ. 2015. Pollen sources used by Apis mellifera Latreille in the semiarid region. Ciência Animal Brasileira 16: 491-497. doi:10.1590/ 1089-6891v16i425538.

Erdtman G. 1960. The acetolysis method. A revised description. Svensk Botanisk Tidskrift 54: 561-564.

Falcão BR, Schlindwein C, Stehmann JR. 2016. Pollen release mechanisms and androecium structure in Solanum (Solanaceae): Does anther morphology predict pollination strategy? Flora - Morphology, Distribution, Functional Ecology of Plants 224: 211-217. doi:10.1016/j.flora.2016.08.001.

Feller-Demalsy MJ, Parent J, Strachan AA. 1987. Microscopic analysis of honeys from Saskatchewan, Canada. Journal of Apicultural Research 26: 47-254.

Gostinski LF, Oliveira FF, Contrera FAL, Albuquerque PMC. 2018. Trophic niche and floral resources partition between two species of Melipona (Hymenoptera, Apidae) in the eastern Amazon. Oecologia Australis 22: 449-462. doi:10.4257/ oeco.2018.2204.08.

Hammer Ø, Harper DAT, Ryan PD. 2001. PAST: Paleontological Statistics software package for education and data analysis. Version 2.17. Paleontologica Eletronica 4: 1-9.

Jones GD, Bryant Junior VM. 2004. The use of ETOH for the dilution of honey. Grana 43: 174-182. doi:10.1080/ 00173130410019497.

Kill LHP, Haji FNP, Lima PCF. 2000. Visitantes florais de plantas invasoras de áreas com fruteiras irrigadas. Scientia Agricola 57: 575-580. doi:10.1590/S0103-90162000000300034.

Lima LR, Mav C-B, Pirani JR, Corrêa MAS. 2007. Pollen morphology of Croton sect. Lamprocroton (Müll. Arg.) Pax (Euphorbiaceae) and its taxonomic implications. Nordic Journal of Botany 25: 206-216. doi:10.1111/j.0107-055X.2007.00076.x.

Lorente FL, Buso Junior AA, Oliveira PE, Pessenda LCR. 2017. Palynological Atlas: 14C Laboratory - Cena/US. Piracicaba: FEALQ.

Louveaux J, Maurizio A, Vorwohl G. 1978. Methods of melissopalynology. Bee World 59: 139-157. doi:10.1080/0005772X.1978. 11097714.

Maia-Silva C, Silva CI, Hrncir M, Queiroz RT, ImperatrizFonseca VL. 2012. Guia de plantas: Visitadas por abelhas na Caatinga (1st ed). Fortaleza: Fundação Brasil Cidadão.

Matos VR, Santos FAR. 2016. Pollen in honey of Melipona scutellaris L. (Hymenoptera: Apidae) in an Atlantic rainforest area in Bahia, Brazil. Palynology 41: 144-156. doi:10.1080/ 01916122.2015 .1115434

Nascimento AS, Carvalho CAL, Sodré GS. 2015. The pollen spectrum of Apis mellifera honey from Reconcavo of Bahia, Brazil. Journal of Scientific Research and Reports 6: 426-438. doi:10.9734/JSRR

Nascimento EA, Del-Claro K. 2007. Floral visitors of Chamaecrista debilis (Vogel) Irwin \& Barneby (Fabaceae - Caesalpinioideae) at Cerrado of Estação Ecológica de Jataí, São Paulo State, Brazil. Neotropical Entomology 36: 619-624. doi:10.1590/S1519-566X2007000400024.

Nogueira-Neto P. 1997. Vida e criação de abelhas indígenas sem ferrão. São Paulo: Nogueirapis.

Novais JS, Absy ML, Santos FAR. 2013. Pollen grains in honeys produced by Tetragonisca angustula (Latreille, 1811) (Hymenoptera: Apidae) in tropical semiarid areas of north-eastern Brazil. Arthropod-Plant Interactions 7: 619-632. doi:10.1007/s11829013-9276-x.

Novais JS, Garcez ACA, Absy ML, Santos FAR. 2015. Comparative pollen spectra of Tetragonisca angustula (Apidae, Meliponini) from the Lower Amazon (N Brazil) and caatinga (NE Brazil). Apidologie 46: 417-431. doi:10.1007/s13592-014-0332-z.

Novais JS, Lima LCL, Santos FAR. 2009. Botanical affinity of pollen harvested by Apis mellifera L. in a semi-arid area from Bahia, Brazil. Grana 48: 224-234. doi:10.1080/00173130903037725.

Nunes-Silva P, Hrncir M, Silva CI, Roldão YS, Imperatriz-Fonseca VL. 2013. Stingless bees, Melipona fasciculata, as eficiente pollinators of eggplant (Solanum melongena) in greenhouses. Apidologie 44: 537-546. doi:10.1007/s13592-013-0204-y.

Oliveira DJ, Carvalho CAL, Sodré GS, Paixão JF, Alves RMO. 2016. Partitioning of pollen resources by two stingless bee species in the North Bahia, Brazil. Grana 56: 285-293. doi:10.1080/00173134.2016.1217040.

Oliveira JPF, Barreto MLJ, Lima Júnior DM, Aguiar EM, Silva TO. 2010. Mesquite (Prosopis juliflora): An alternative to feed sheep in Northeastern Brazil. Revista Verde 5: 1-4.

Oliveira PP, Santos FAR. 2014. Prospecção palinológica em méis da Bahia. Feira de Santana: Print Mídia.

Osterkamp IC, Jasper A. 2013. Análise palinológica em méis da região do vale do Taquari, Rio Grande do Sul, Brasil: Ferramenta para a definição de origem botânica. Revista Destaques Acadêmicos 5: 111-119.

Pagano MC, Araújo FS. 2010. Semiarid vegetation in Brazil: Biodiversity, impacts and management. In: Degenovine KM, ed. Semi-arid environments: Agriculture, water supply, 1-17. New York: Nova Science Publishers.

Punt W, Hoen PP, Blackmore S, Nilsson S, Le Thomas A. 2007. Glossary of pollen and spore terminology. Review of Palaeobotany and Palynology 143: 1-81. doi:10.1016/j.revpalbo.2006.06.008.

Queiroz LP, Conceição A, Giulietti AM. 2006. Nordeste Semi-árido: Caracterização geral e lista das fanerógamas. In: Giulietti AM, Queiroz LP, eds. Instituto do Milênio do Semi-árido: Diversidade e caracterização das fanerógamas do semi-árido brasileiro, 15364. Recife: APNE.

Ramalho IC, Andrade A, Felix LP, Lacerda AV, Maracaja P. 2009. Flora arbóreo-arbustiva em áreas de caatinga no semiárido baiano, Brasil. Revista Caatinga 22: 178-186.

Roubik DW, Moreno JEP. 1991. Pollen and Spores of Barro Colorado Island. St Louis, MO: Monographs in Systematic Botany.

Santana ALA, Fonseca AAO, Alves RMO, Carvalho CAL, Melo PA, Silva ES, Souza BA, Jesus JN, Sodré GS. 2011. Pollen types in honey samples of stingless bees from municipalities in the semiarid baiano. Magistra 139: 23-134.

Santos FAR, Carneiro CE. 2015. De Melle Semiaridi: Analisando o mel Nordestino. Salvador: EDUFBA.

Silva APC, Santos FAR. 2014. Pollen diversity in honey from Sergipe, Brazil. Grana 53: 159-170. doi:10.1080/00173134.2014.89 6941.

Silva TMS, Santos FP, Evangelista-Rodrigues A, Silva EM, Silva GS, Novais JS, Santos FAR, Camara CA. 2013. Phenolic compounds, melissopalynological, physicochemical analysis and antioxidant activity of jandaíra (Melipona subnitida) honey. Journal of Food Composition and Analysis 29: 1018. doi:10.1016/j.jfca.2012.08.010.

Sousa JKG, Costa HB, Guimarães-Brasil MO, Brasil DF, Souza EA. 2016b. Frequency and behavior of floral visitors in mesquite (Prosopis juliflora (Sw) DC.) in Alexandria - RN. Agropecuária Científica no Semiárido 12: 221-229.

Sousa JM, Souza ELB, Marques G, Meireles B, Cordeiro ATM, Gullón B, Pintado MM, Magnani M. 2016a. Polyphenolic profile and antioxidant and antibacterial activities of monofloral honeys produced by Meliponini in the Brazilian semiarid region. Food Research International 84: 61-68. doi:10.1016/j.foodres.2016.03.012.

Souza LS, Lucas CIS, Conceição PJ, Paixão JF, Alves RMO. 2015. Pollen spectrum of the honey of uruçu bee (Melipona 
scutellaris Latreille, 1811) (Hymenoptera: Apidae) in the North Coast of Bahia State. Acta Scientiarum 37: 483489. doi:10.4025/actasciagron.v37i4.19676.

Tsutsumi LH, Oishi DE. 2010. Farm and forestry production and marketing profile for honey bees (Apis mellifera). In: Elevitch CR, ed. Specialty crops for Pacific Island agroforestry, 1-29. Holualoa: Permanent Agriculture Resources (PAR).

Velloso AL, Sampaio EVSB, Pareyn FG. 2002. Ecorregiões: Propostas para o Bioma Caatinga. TNC-Brasil, Associação
Plantas do Nordeste, Recife. Recife: Associação Plantas do Nordeste.

Willmer P. 2011. Pollination and floral ecology. Branford, CT: Princeton University Press.

Ybert JP, Carvalho MA, Scheel-Ybert R. 2018. Grãos de pólen de plantas vasculares do Estado do Rio de Janeiro, Brasil: Volume IV. Rio de Janeiro: Museu Nacional.

Ybert JP, Scheel-Ybert R, Carvalho MA. 2017. Grãos de pólen de plantas vasculares do Estado do Rio de Janeiro, Brasil: Volume III. Rio de Janeiro: Museu Nacional. 